\title{
Proteolytic action of the crude extract of Duddingtonia flagrans on cyathostomins (Nematoda: Cyathostominae) in coprocultures
}

\author{
Ação proteolítica do extrato bruto de Duddingtonia flagrans sobre ciatostomíneos
}

(Nematoda: Cyathostominae) em coproculturas

\author{
Fabio Ribeiro Braga ${ }^{1,2 *}$; Jackson Victor de Araújo ${ }^{1}$; Filippe Elias de Freitas Soares ${ }^{3}$; Juliana Milani Araujo ${ }^{1}$; \\ Sebastiāo Rodrigo Ferreira ${ }^{1}$; Alexandre de Oliveira Tavela ${ }^{1}$; Wendeo Ferreira da Silveira ${ }^{1}$; José Humberto de Queiroz ${ }^{3}$ \\ ${ }^{1}$ Departamento de Veterinária, Universidade Federal de Viçosa - UFV, Viçosa, MG, Brasil \\ ${ }^{2}$ Universidade Vila Velha - UVV, Vila Velha, ES, Brasil \\ ${ }^{3}$ Departamento de Bioquímica e Biologia Molecular, Universidade Federal de Minas Gerais - UFMG, Belo Horizonte, MG, Brasil \\ Received January 12, 2012 \\ Accepted May 10, 2012
}

\begin{abstract}
The objective of this study was to examine the action of the crude extract of Duddingtonia flagrans (isolates AC001 and CG722) on infective larvae $\left(\mathrm{L}_{3}\right)$ of cyathostomins in coprocultures and to confirm its proteolytic activity by means of a zymogram. The following groups were formed in coprocultures: Group 1: $10 \mathrm{~mL}$ of crude extract of $D$. flagrans

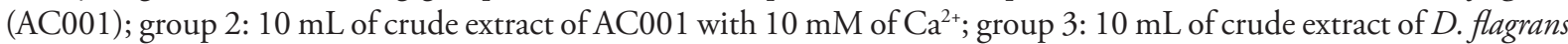

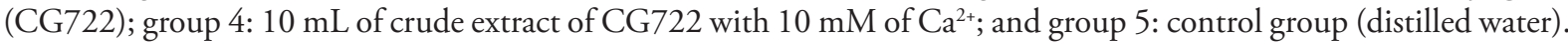
The third-stage larvae $\left(\mathrm{L}_{3}\right)$ were obtained after eight days. The crude extract of $D$. flagrans was effective in reducing the number of $\mathrm{L}_{3}$, with the following percentage reductions: group $1,49.5 \%$; group $2,52.5 \%$; group $3,36.8 \%$; and group 4, 57.7\%; in relation to the control group ( $p>0.05)$. The proteolytic activity of the crude extract was confirmed through the zymogram. The results from this study confirmed that the crude extract of the fungus $D$. flagrans could be used for controlling cyathostomin $\mathrm{L}_{3}$, and suggested that at least one protease of approximately $38 \mathrm{kDa}$ was present.

Keywords: Nematophagous fungi, Duddingtonia flagrans, zymogram, nematode, horses.
\end{abstract}

\section{Resumo}

O objetivo deste trabalho foi estudar a ação do extrato bruto de Duddingtonia flagrans (isolados AC001 e CG722) sobre larvas infectantes $\left(\mathrm{L}_{3}\right)$ de ciatostomíneos em coproculturas e confirmar a sua atividade proteolítica por meio de um zimograma. Foram formados os seguintes grupos em coproculturas: grupo 1: $10 \mathrm{~mL}$ de extrato bruto de $D$. flagrans (AC001); grupo 2: $10 \mathrm{~mL}$ de extrato bruto de AC001 com íons $\mathrm{Ca}^{2+} 10 \mathrm{Mm}$; grupo 3: $10 \mathrm{~mL}$ de extrato bruto de D. flagrans (CG722); grupo 4: $10 \mathrm{~mL}$ de extrato bruto de CG722 com íons $\mathrm{Ca}^{2+} 10 \mathrm{Mm}$; e grupo 5 como controle (água destilada), obtendo-se as $\mathrm{L}_{3}$ ao final de 8 dias. $\mathrm{O}$ extrato bruto de $D$. flagrans foi eficiente na redução do número de $\mathrm{L}_{3}$ com os seguintes percentuais de redução: grupo 1 (49,5\%); grupo 2 (52,5\%); grupo 3 (36,8\%) e grupo 4 (57,7\%) em relação ao grupo controle $(\mathrm{p}>0,05)$. Confirmou-se a atividade proteolítica por meio do zimograma. Os resultados do presente trabalho confirmam a utilização do extrato bruto do fungo $D$. flagrans no controle de $\mathrm{L}_{3}$ de ciatostomíneos e sugere a presença de pelo menos uma protease de aproximadamente $38 \mathrm{kDa}$.

Palavras-chave: Fungos nematófagos, Duddingtonia flagrans, zimograma, nematóides, cavalos.

Horses are hosts for a wide variety of helminths, and among these, the most important are the cyathostomins, also known as "small strongyles". In the literature, cyathostomins have been described as the most numerous group in horses, particularly focusing on: (1) their diversity of species; (2) the number of specimens per host; and (3) infective larvae that are present in

\footnotetext{
*Corresponding author: Fabio Ribeiro Braga

Departamento de Veterinária, Universidade Federal de Viçosa - UFV,

Av. Ph Rolf, s/n, CEP 36570-000, Viçosa, MG, Brasil

e-mail: fabioribeirobraga@hotmail.com
}

pastures throughout the year (LOVE et al., 1992; EYSKER et al., 1989; COUTO et al., 2008; QUINELATO et al., 2008). With regard to direct damage caused to the hosts, cyathostomins can cause episodes of colic and diarrhea in adult animals (BIRD; HERD, 1995; MURPHY; LOVE, 1997; BRAGA et al., 2009, 2010). They are controlled through using of anthelmintics but, except for some situations, such treatments have not been totally effective (KAPLAN, 2002).

The majority of these parasites develop their first larval stages $\left(\mathrm{L}_{1}\right.$ to $\left.\mathrm{L}_{2}\right)$ inside a fecal mass, feeding on microorganisms and 
organic matter. However, for nematode parasites of animals to progress to the $\mathrm{L}_{3}$ phase of their development, they need to find a host (MONTEIRO, 2011). In this context, use of nematophagous fungi that destroy $\mathrm{L}_{3}$ in the environment has been exhaustively studied with promising results, both under natural and under laboratory conditions. Most of these studies mention interactions of fungi versus nematodes in solid media cultures and use of conidia, chlamydospores and mycelial masses (LARSEN et al., 1995; BRAGA et al., 2009; TAVELA et al., 2011). Use of crude extracts originating from these microorganisms against infective stages of gastrointestinal nematode parasites has recently been addressed (BRAGA et al., 2011b, c). However, there is an increasing need to elucidate the real possibility of using these extracts under partially natural conditions, such as coprocultures. Moreover, the species Duddingtonia flagrans produces extracellular enzymes that are observed in its crude extract, which cause hydrolysis of the cuticle of nematodes, thus allowing this fungus to also act inside the nematode and leading to its destruction (BRAGA et al., 2011c).

The objectives of this study were to examine the action of a crude extract from D. flagrans (isolates AC001 and CG722) on cyathostomins in coprocultures and to confirm its proteolytic activity by means of a zymogram.

Fresh feces collected directly from the rectum of horses naturally infected with cyathostomins were used. These animals were kept at the Department of Veterinary Medicine, Federal University of Viçosa.

Two isolates of the nematophagous fungus Duddingtonia flagrans (AC001 and CG722) were used to produce the crude extract. These isolates originated from Brazilian soil and had been maintained through continuous transfer to solid culture media in the Parasitology Laboratory of the Veterinary Department of the Federal University of Viçosa. To produce the crude extract, mycelia of this fungus were obtained by firstly transferring culture discs (about $5 \mathrm{~mm}$ in diameter) to previously autoclaved flasks containing $50 \mathrm{~mL}$ of liquid medium. Next, the flasks containing the fungal inoculum were placed in a shaker and the fungus was allowed to grow under agitation of $120 \mathrm{X} g$ for six days. Following this, the supernatant was collected and filtered using Whatman No. 1 filter paper at $4{ }^{\circ} \mathrm{C}$. The methodology for producing and obtaining the crude extract was based on the study by Braga et al. (2011c).

To perform the experimental assay, coprocultures were first produced in accordance with the technique described by Gordon and Whitlock (1939), in which $20 \mathrm{~g}$ of positive feces were mixed with fragmented and moistened industrial vermiculite that had been autoclaved. Different groups of coprocultures were then formed: group 1: $10 \mathrm{~mL}$ of crude extract of $D$. flagrans (AC001); group 2: $10 \mathrm{~mL}$ of crude extract of AC001 with $10 \mathrm{mM}$ of $\mathrm{Ca}^{2+}$; group 3: $10 \mathrm{~mL}$ of crude extract of $D$. flagrans (CG722); group 4: $10 \mathrm{~mL}$ of crude extract of CG722 with $10 \mathrm{mM}$ of $\mathrm{Ca}^{2+}$; and group 5, control (distilled water). The extracts were added to the coprocultures and this material was then placed in a heated chamber at $26{ }^{\circ} \mathrm{C}$ for 8 days. Six replicates were performed for each group. At the end of this period, third-stage larvae $\left(\mathrm{L}_{3}\right)$ were obtained using the Baermann method. These were identified and quantified using the criteria described by Bevilaqua et al. (1993), under an optical microscope with a $10 \times$ objective. The data thus obtained were interpreted by means of analysis of variance and the efficiency of destruction of $\mathrm{L}_{3}$ in relation to the control group was assessed using the Tukey test at a 5\% probability level (AYRES et al., 2003). Subsequently, the average percentage reduction of larvae was calculated according to the following equation:

$$
\% \text { Reduction }=\left[\begin{array}{cc}
\overline{\mathrm{x}} \text { of larvae } & \overline{\mathrm{x}} \text { of larvae } \\
\text { from control } & \text { from treatment }
\end{array}\right] \times 100
$$

Next, in order to confirm that proteolytic activity was occurring in the crude extract of the fungus D. flagrans (AC001 and CG722), a zymogram was produced using casein as the substrate (Casein-SDS-PAGE), as described by Hummel et al. (1996) with some modifications. The samples were subjected to electrophoresis on a $10 \%$ polyacrylamide gel containing $1 \%$ casein. The samples were mixed with carrier buffer (without $\beta$-mercaptoethanol) and applied without prior heating. After electrophoresis, the gel was incubated in a solution of $2.5 \%$ Triton $\mathrm{X}-100$ for one hour, followed by three washes with water. The gel was then incubated in $50 \mathrm{mM}$ of Tris- $\mathrm{HCl}$ reaction buffer ( $\mathrm{pH}$ 8.0) for one hour at $60{ }^{\circ} \mathrm{C}$. For further development, the gel was stained with Coomassie Brilliant Blue R-250 and was bleached soon afterwards. The presence of enzyme action can be seen through formation of white halos.

At the end of the eight-day period, analysis on the coprocultures showed that in the experimental assay, the crude extract of $D$. flagrans (AC001 and CG722) had been effective in reducing the number of $\mathrm{L}_{3}$ cyathostomins, as seen using the Baermann technique (Figure 1). The following percentage reductions were observed for each of the groups: group 1, 49.5\%; group 2, 52.5\%; group 3, 36.8\%; and group 4, 57.7\%. However, no differences $(\mathrm{p}>0.05)$ in $\mathrm{L}_{3}$ recovery were observed in the treated groups. This was not observed in the control group $(\mathrm{p}<0.05)$. The zymogram confirmed that proteolytic activity was occurring in the crude extract produced from D. flagrans (AC001 and CG722), through the observation that the enzymatic action produced a halo of casein digestion up to a height of approximately $38 \mathrm{kDa}$.

The fecal environment is where most of the evolutive cycle of nematodes is developed: from eggs to the infective stage, in this case $\mathrm{L}_{3}$ (MONTEIRO, 2011). In this context, some studies have shown that use of nematophagous fungi may be a promising alternative for reducing the quantity of infective forms present in the environment, given that conidia, chlamydospores and even mycelial masses have been used successfully (CHARLES et al., 1995; CASTRO et al., 2003; CAMPOS et al., 2008; BRAGA et al., 2011c; SILVA et al., 2010). On the other hand, crude extract has recently also been used as an approach towards combating the eggs and/or larvae of gastrointestinal nematode parasites (BRAGA et al., $2011 \mathrm{a}, \mathrm{c})$. In the present study, coprocultures were used with the purpose of mimicking the fecal environment and, in this case, the results were very promising given that there was a reduction in the number of $\mathrm{L}_{3}$ recovered in relation to the control.

Regarding the action of ions that interfere directly in the proteolytic activity of nematophagous fungi, a recent study by Braga et al. (2011b) showed that the ions $\mathrm{Cu}^{2+}, \mathrm{Zn}^{2+}$ and $\mathrm{Mg}^{2+}$ inhibited their activity, while $\mathrm{Ca}^{2+}$ had a positive effect on the proteolytic activity of the extract of the fungus $D$. flagrans (AC001). 


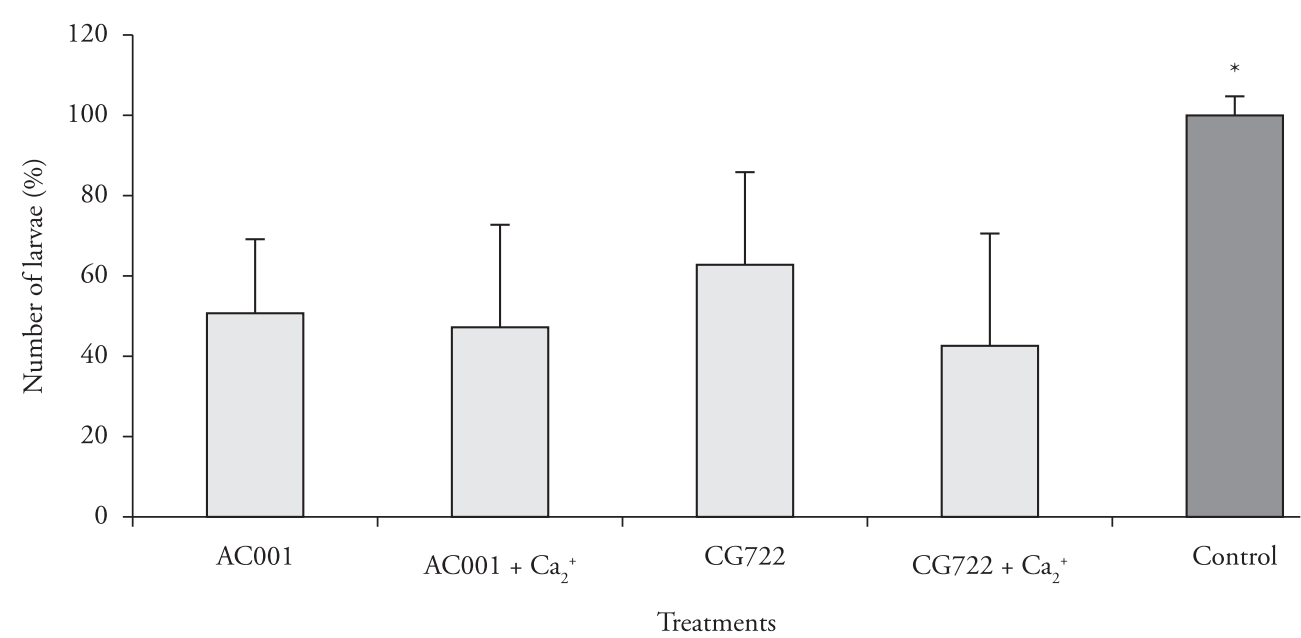

Figure 1. Mean and standard deviations of $\mathrm{L}_{3}$ cyathostomins recovered after eight days of coproculture with a crude extract from the fungus Duddingtonia flagrans (AC001 or CG722), with or without added $\mathrm{Ca}^{2+}$, in relation to a control group. There was a significant difference $(\mathrm{p}<0.05)$ between the group treated with fungus and the control (asterisk), as seen using the Tukey test.

These results are in agreement with the present study, since it was observed that the crude extract (AC001 or CG722) with added $\mathrm{Ca}^{2+}$ showed a higher percentage reduction in the number of $\mathrm{L}_{3}$ recovered, in relation to when it was used without addition of $\mathrm{Ca}^{2+}$. Furthermore, it could also be seen that the result described above for the isolate AC001 in this study was in accordance with the result demonstrated for the isolate CG722.

$D$. flagrans is considered to be the most promising species for use in biological control for combating gastrointestinal nematode parasites of domestic animals, both under laboratory conditions and in the field, and in particular in relation to horses (CAMPOS et al., 2008; BRAGA et al., 2009). However, there is a deficiency of studies aimed towards making certain comparisons between the different isolates of D. flagrans, in relation to: (1) their predatory activity; (2) lack of information about the proteolytic action of the crude extract of the isolate CG722 (the present study has provided the first report on this); and (3) confirmation that the two isolates have identical proteolytic profiles.

Bird and Herd (1995) and Kaplan (2002) reported that no drugs were effective against encysted larval stages of cyathostomins, and that this was a major obstacle to combating this nematodiasis. This information is important and provides justification for the present study, since the results suggest that pre-parasitic forms of cyathostomins need to be controlled. Such methods may lead to alternative control techniques that could be used to reduce the number of $\mathrm{L}_{3}$ in the fecal environment and, thus, in pastures. This form of control may, in the future, come to be a further tool for reducing recurrences of cyathostomin infections.

The results from the present study confirmed that the crude extract of the fungus D. flagrans (AC001 or CG722) could be used for controlling cyathostomin $\mathrm{L}_{3}$. The proteolytic profile suggested that at least a protease of approximately $38 \mathrm{kDa}$ was present, which could be used for biological control over the $\mathrm{L}_{3}$ of this nematode.

\section{Acknowledgements}

The authors thank CAPES, CNPq and FAPEMIG for their financial support.

\section{References}

Ayres M, Ayres Junior M, Ayres DM, Santos AS. BioEstat 3.0: Aplicações estatísticas nas áreas de ciências biológicas e médicas. Belém: Sociedade civil mamirauá; Brasília CNPq; 2003. p. 290.

Braga FR, Araújo JV, Silva AR, Araujo JM, Carvalho RO, Ferreira SR, et al. Predatory activity of the nematophagous fungus Duddingtonia flagrans on horse cyathostomin infective larvae. Trop Anim Health Prod 2010; 42(6): 1161-1165. PMid:20213221. http://dx.doi. org/10.1007/s11250-010-9542-1

Braga FR, Araújo JV, Silva AR, Araujo JM, Carvalho RO, Tavela $\mathrm{AO}$, et al. Biological control of horse cyathostomin (Nematoda: Cyathostominae) using the nematophagous fungus Duddingtonia flagrans in tropical southeastern Brazil. Vet Parasitol 2009; 163(4): 335-340. PMid:19497672. http://dx.doi.org/10.1016/j.vetpar.2009.05.003

Braga FR, Araújo JV, Soares FEF, Araujo JM, Geniêr HLA, Silva $\mathrm{AR}$, et al. Optimizing protease production from an isolate of the nematophagous fungus Duddingtonia flagrans using response surface methodology and its larvicidal activity on horse cyathostomin. J Helminthol 2011a; 85(2): 164-170. PMid:20682085. http://dx.doi. org/10.1017/S0022149X10000416

Braga FR, Araújo JV, Soares FEF, Araujo JM, Ferreira SR, Frassy LN, et al. Production and partial characterization of Duddingtonia flagrans (AC001) crude extract and its in vitro larvicidal action against trichostrongylid infective larvae. Biocontrol Sci Technol2011b; 21(11): 1313-1320. http:// dx.doi.org/10.1080/09583157.2011.619258

Braga FR, Araujo JM, Tavela AO, Araújo JV, Soares FEF, Geniêr HLA, et al. Atividade larvicida do extrato bruto enzimático do fungo Duddingtonia flagrans sobre larvas de primeiro estádio de Angiostrongylus vasorum. Rev Soc Bras Med Trop 2011c; 44(3): 383-385. PMid:21779678. 
Bevilaqua CML, Rodrigues ML, Concordet D. Identification of infective larvae of some common nematode strongylids of horses. Revue Méd Vét 1993; 144(142): 989-995.

Bird J, Herd RP. In vitro assessment of two species of nematophagous fungi (Arthrobotrys oligospora and Arthrobotrys flagrans) to control the development of infective cyathostome larvae from naturally infected horses. Vet Parasitol 1995: 56(1-3); 181-187. http://dx.doi. org/10.1016/0304-4017(94)00663-W

Campos AK, Araújo JV, Guimarães MP. Interaction between the nematophagous fungus Duddingtonia flagrans and infective larvae of Haemonchus contortus (Nematoda: Trichostrongyloidea). J Helminthol 2008; 82(4): 337-341. PMid:18620628. http://dx.doi. org/10.1017/S0022149X08032203

Castro AA, Oliveira CRC, Anjos DHS, Ornelas EI, Bittencourt VREP, Araújo JV, et al. Potencial dos fungos nematófagos Arthrobotrys sp. E Monacrosporium thaumasium para o controle de larvas de ciatostomíneos de eqüinos (Nematoda: Cyathostominae). Rev Bras Parasitol Vet 2003; 12(2): 53-57.

Charles T, Rodrigues MLA, Santos CP. Redução do número de larvas de Cyathostominae em fezes de eqüinos tratadas com conídeos de Arthrobotrys oligospora. Arq Bras Med Vet Zoo 1995; 47(1): 87-89.

Couto MCM, Quinelato S, Santos CN, Souza LS, Sampaio IBM, Rodrigues MLA. Environmental influence in cyathostominae ecology. Vet Med 2008; 53(5): 243-249.

Eysker M, Boersema JH, Kooyman FNJ. Emergence from inhibited development of cyathostome larvae in ponies following failure to remove them by repeated treatments with benzimidazole compounds. Vet Parasitol 1989; 34(1-2): 87-93. http://dx.doi.org/10.1016/03044017(89)90168-4

Gordon HM, Whitlock HV. A new technique for counting nematode eggs in sheep faeces. J Council Scient Ind Res 1939; 12: 50-52.
Kaplan RM. Anthelmintic resistance in nematodes of horses. Vet Res 2002; 33(5): 491-507. PMid:12387486. http://dx.doi.org/10.1051/ vetres: 2002035

Larsen M, Nansen P, Wolstrup J, Gronvold J, Henriksen S, Zorn A. Biological control of trichostrongyles in calves by the fungus Duddingtonia flagrans fed to animals under natural grazing conditions. Vet Parasitol 1995; 60(3-4): 321-330. http://dx.doi.org/10.1016/03044017(95)00791-6

Love S, Duncan JL. The development of naturally acquired cyathostome infection in ponies. Vet Parasitol 1992; 44(1-2): 127-142. http://dx.doi. org/10.1016/0304-4017(92)90151-X

Murphy D, Love S. The pathogenic effects of experimental cyathostome infections in ponies. Vet Parasitol 1997; 70(1-3): 99-110. http://dx.doi. org/10.1016/S0304-4017(96)01153-3

Hummel KM, Penheiter AR, Gathman AC, Lilly WW. Anomalous estimation of protease molecular weights using gelatin containing SDSPAGE. Anal Biochem 1996; 233(1): 140-142. PMid:8789159. http:// dx.doi.org/10.1006/abio.1996.0019

Monteiro SG. Parasitologia na Medicina Veterinária. Roca, 2011.356 p.

Quinelato S, Couto MCM, Ribeiro BC, Santos CN, Souza LS, Anjos HS, et al. The ecology of horse cyathostomin infective larvae (Nematoda-Cyathostominae) in tropical southeast Brazil. Vet Parasitol 2008; 153(1-2): 100-107. PMid:18329175. http://dx.doi. org/10.1016/j.vetpar.2008.01.027

Silva BF, Mauad JRC, Braga FR, Campos AK, Araújo JV, Amarante AFT. Efficacy of Duddingtonia flagrans and Arthrobotrys robusta in controlling sheep parasitic gastroenteritis. Parasitol Res 2010; 106(6): 1343-1350. PMid:20237801. http://dx.doi.org/10.1007/s00436-010-1805-2

Tavela AO, Araújo JV, Braga FR, Silva AR, Carvalho RO, Araujo JM, et al Biological control of cyathostomin (Nematoda: Cyathostominae) with nematophagous fungus Monacrosporium thaumasium in tropical southeastern Brazil. Vet Parasitol 2011; 175(1-2): 92-96. PMid:21035270. http://dx.doi.org/10.1016/j.vetpar.2010.09.035 